\title{
KOMUNITAS LA PIAZZA
}

\author{
Arnold Christianto Oenang ${ }^{1)}$, Sutarki Sutisna ${ }^{21}$
}

1)Program Studi S1 Arsitektur, Fakultas Teknik, Universitas Tarumanagara, arnoldoenang@gmail.com
2) Program Studi S1 Arsitektur, Fakultas Teknik, Universitas Tarumanagara, sutarkis@gmail.com

\begin{abstract}
Abstrak
Manusia adalah makhluk sosial yang membutuhkan kehadiran orang lain untuk melengkapi hidupnya dan memiliki tempat untuk melakukan aktifitas tersebut. Kebutuhan inilah yang kemudian yang menjadi latar belakang terbentuknya ruang publik. Dengan adanya perkembangan jaman dan teknologi, kebutuhan akan sebuah ruang publik untuk melakukan aktivitas semakin banyak. Ruang tersebut disebut sebagai tempat ketiga oleh sosiologis Ray Oldenburg. La Piazza merupakan salah satu tempat yang dapat disebut sebagai tempat ketiga, namun tempat tersebut ditutup karena kurang berjalan dengan baik. Tujuan desain ini untuk mengaktifkan kembali fungsi La Piazza sebagai tempat ketiga di Kelapa Gading. La Piazza Third place memiliki desain yang baru mengutamakan konsep open architecture dan architecture for the Third place juga konsep hutan. sehingga desain pada bangunan baru selain memiliki ruang - ruang yang terbuka untuk umum dan ruang komunitas, juga memberikan kesan terbuka dan mengundang serta sejuk dan tenang. Dalam proyek ini beberapa struktur eksisting pada bangunan lama digunakan kembali, seperti basement, konektor menuju gedung parkir, konektor menuju mall kelapa gading, dan struktur dari eksisting gedung La Piazza bagian utara. Terdapat 3 elemen hutan yang diterapkan pada bangunan, yaitu air, tanaman hijau dan cahaya matahari. 3 hal tersebut dapat merelaksasi orang yang sedang banyak pikiran dan stress akan pekerjaan khususnya orang - orang yang bekerja di kantoran, menurut penelitian regent's university london.
\end{abstract}

\section{Kata kunci: hijau; kelapa gading; la piazza; ruang terbuka; tempat ketiga}

\begin{abstract}
Humans are social creatures who need the presence of others to complete their lives and have a place to do these activities. These needs are then the background for the formation of public space. With the changing times and technology, the need for a public space to do more and more activities. The space is referred to as the Third place by sociologist Ray Oldenburg. La Piazza is one place that can be called a Third place, but the place was closed because it was not going well. The purpose of this design is to reactivate the function of La Piazza as a Third place in Kelapa Gading. La Piazza Third place has a new design that emphasizes the concept of open architecture and architecture for the Third place as well as the concept of forests. so the design of the new building in addition to having spaces that are open to the public and community space, also gives the impression of being open and inviting as well as cool and calm. In this project, some existing structures in the old building were reused, such as basements, connectors to the parking building, connectors to the ivory coconut mall, and structures from the existing northern La Piazza building. There are 3 forest elements applied to buildings, namely water, greenery and sunlight. These 3 things can relax people with a lot of thoughts and stress about work, especially those who work in offices, according to Regent's University London research.
\end{abstract}

Keywords: green; kelapa gading; la piazza; open space; Third place 


\section{PENDAHULUAN}

Manusia adalah makhluk sosial yang membutuhkan kehadiran orang lain untuk melengkapi hidupnya dan membutuhkan tempat untuk melakukan aktivitas tersebut. Kebutuhan inilah yang kemudian yang menjadi latar belakang terbentuknya ruang publik. Menurut Permen PU Nomor 05/PRT/M/2008 Ruang publik (Public Space) didefinisikan sebagai ruang/tempat dimana setiap orang dapat bebas keluar masuk tanpa dipungut suatu bayaran. Contohnya jalan dan taman umum dimana setiap orang bebas masuk dan menggunakannya. Karena memiliki sifat bisa digunakan atau dimasuki setiap orang, ruang publik tidak mempertimbangkan aspek privasi bagi penggunanya.

Ruang publik memberikan warna dalam kehidupan masyarakat dan dibutuhkan untuk meresponi ruang-ruang yang rutin ditemukan dalam kehidupan masyarakat seperti tempat tinggal dan tempat bekerja. Di ruang publik inilah terjadi pertukaran dan pergerakan energi yang menggerakan dan menghidupkan lingkungan tersebut. Seiring dengan adanya perkembangan jaman dan teknologi, prilaku masyarakatpun berubah dan kebutuhan akan ruang publik untuk melakukan kegiatan nonformal semakin meningkat. Ruang tersebut disebut sebagai The Third place oleh sosiologis Ray Oldenburg. The Third place (ruang/tempat ketiga) adalah ruang/tempat dimana orang dapat berkumpul dan beraktivitas (gathering) dengan komunitas masyarakat, selain tempat tinggal (the first place) dan tempat bekerja (the second place). Suatu tempat, dapat dibilang Third place jika memiliki 8 kriteria yaitu netral, level, conversation accessible, regulars, plain, unpretentious and playfull. Delapan kriteria ini dapat berubah-ubah sesuai dengan pandangan masing-masing individu. Beberapa contoh tempat ketiga menurut Oldenburg yaitu tempat ibadah, kafe, club, perpustakaan umum, plaza dan taman, sehingga dapat disimpulkan bahwa suatu tempat dapat dikatakan sebagai tempat ketiga / Third place bergantung pada masing-masing perspektif individu.

La Piazza merupakan bahasa Itali yang memiliki arti The Plaza dalam bahasa inggris. Plaza merupakan sebuah lapangan terbuka untuk umum di daerah perkotaaan. La Piazza terkenal dengan live music dan tempat berkumpulnya. Namun sayang pada tahun 2017 La Piazza ditutup, menurut bapak agus satpam yang berjaga disana, La Piazza ditutup akibat tidak berfungsi dengan baik. Menurut hasil survei, ada 3 hal yang membuat La Piazza tidak berfungsi dengan baik, yaitu, desain yang memiliki kesan tertutup dan eksklusif, membuat orang ekonomi menengah kebawah segan untuk masuk ke dalamnya. Hal yang ke dua yaitu, lapangan terbuka yang memiliki sedikit vegetasi sehingga membuat lapangan tersebut gersang saat siang hari. Dan yang terakhir, adalah prilaku pengguna La Piazza yang sering berkumpul tanpa membeli apaapa. Dengan adanya proyek ini, diharapkan La Piazza dapat menjadi suatu tempat berkumpul untuk melakukan aktivitas bersama dengan komunitas di Kelapa Gading, dengan konsep Third place, open space, memiliki banyak tanaman hijau, dan dapat menjadi tempat ketiga bagi orangorang yang bekerja di Kelapa Gading serta mengaktifkan kembali fungsi La Piazza sebagai ruang terbuka umum di Kelapa Gading.

\section{KAJIAN LITERATUR}

Untuk mendukung pembuatan skripsi ini penulis menggali informasi dari beberapa buku dan juga beberapa pendapat dari arsitek indonesia sebagai acuan untuk mendapatkan landasan teori yang benar.

\section{The Great Good Place (Oldernburg, 1989)}

Menurut Oldenburg "tempat pertama/ first place" merupakan rumah atau tempat tinggal seseorang. Tempat kedua / second place merupakan tempat kerja - di mana orang mungkin menghabiskan sebagian besar waktu mereka disana. Tempat ketiga atau Third place merupakan "jangkar" kehidupan komunitas yang memfasilitasi dan mendorong interaksi yang lebih luas dan lebih kreatif. Dengan kata lain, " tempat yang sering didatangi orang untuk berinteraksi secara informal " beberapa contoh Third place menurut Oldenburg yaitu lingkungan gereja, cafe, club, 
perpustakaan umum, atau taman. Menurut pandangan Oldenburg, tempat ketiga dibagi menjadi 8 karakteristik:

a. Tanah Netral, pengguna tempat ketiga tersebut bebas untuk keluar dan masuk sesuka hati mereka tanpa dipungut suatu bayaran dan kepentingan tertentu seperti bekerja di tempat itu.

b. Level (Samarata), tempat ketiga tidak mementingkan status sosial individu, semua umur, ras, agama, pekerjaan, tingkatan sosial, gender boleh datang ke tempat tersebut.

c. Percakapan adalah aktivitas utama, aktivitas utama pada tempat ketiga adalah percakapan, percakapan yang santai, senang, tidak jarang disertai candaan. Percakapan merupakan aktivitas utama namun tidak hanya percakapan saja yang dilakukan dalam tempat ketiga.

d. Aksesibilitas dan akomodasi, tempat ketiga harus terbuka saat orang membutuhkannya. Tempat ketiga juga harus dapat mengakomodasi kemauan dari pengunjungnya.

e. Pengunjung Tetap, tempat ketiga memiliki pengunjung tetap. pengunjung tetap secara tidak langsung juga memberikan warna dan juga menarik orang-orang baru untuk datang ketempat tersebut.

f. Low Profile, tempat ketiga secara karakteristik sehat. Bagian dalam atau interior tempat ketiga memiliki kesan yang sederhana. Tempat ketiga tidak memberikan kesan sombong, dan menerima semua jenis individu, dari berbagai lapisan masyarakat.

g. Mood Menyenangkan (Playfull), mood yang ada pada tempat ketiga adalah menyenangkan, hangat, dan nyaman. Tidak jarang dalam berinteraksi timbul canda dan tawa.

h. Rumah jauh dari rumah, pengunjung pada tempat ketiga terkadang memiliki rasa kehangatan dan kepemilikan yang sama seperti mereka berada di rumahnya. Perasaan dimana mereka merupakan bagian dari tempat tersebut.

\section{Rethinking Oldenburg: Third places and Generation Y in a Developing Country Context (Crick, 2011)}

Tempat ketiga adalah tempat di mana orang bertemu secara teratur untuk bersantai di luar rumah atau bekerja. Terdapat perbedaan cara pandang terhadap tempat ketiga dikalangan Generasi $Y$, bagaimana mereka memahami dan menggunakan tempat ketiga di negara berkembang. Namun memiliki tujuan yang sama yaitu untuk berinteraksi dengan sesama dan bersantai diluar rumah atau tempat kerja.

\section{Menurut Suwardana Winata, M.Arch.}

Third place dalam konteks kota, merupakan sebuah tempat yang dapat mengakomodir kebutuhan masyarakat kota yang beragam, hectic, serba cepat, rutin dan juga dinamis. Tempat ini sesuai dengan difinisi Oldenburg merupakan tempat yang bukan workplace tetapi juga bukan homeplace. Masyarakat yang keluar dari third space haruslah menjadi senang, karena dapat keluar sementara dari kepenatan rutinitas. Third place dalam konteks kota, tidak exculsive melainkan tempat yang terbuka bagi siapapun. Walaupun merupakan tempat yang menerima siapapun, Third place tetap memiliki program-program pendukung agar dapat berfungsi dan beroperasi sesuai dengan rencana. Selain itu juga memiliki program binary (regulated not regulated, paid not paid, serve to be served dan lain -lain) yang tujuan utamanya yaitu terbuka (open space open structure). Third place bukan sebuah shopping center, bukan tempat bermain (playground), bukan pusat rekreasi (recreational center) dan juga bukan tempat sharing bekerja (co-working space/place). Third place adalah tempat yang menyeimbangkan berbagai macam hal (natural-buatan, serius tidak serius, learning-playing, dan lain -lain) dengan tujuan utama bertemu, berbincang-bincang (rendevouz), berkumpul, sharing. Menurut Ir. Agustinus Sutanto M.Arch., Ph.D. Third place memiliki rumusan sebagai berikut, Dalam mendesain Third place terdapat tiga acuan utama, yaitu Openess, Contextuality dan Flexibility. Dimana didalam openess terdapat kesetaraan, dunia orang baru (tak dikenal), ruang permeabel, dan flow informasi yang jelas dan terus-meneurs. Dalam contextuality ada indentitas lokal yang tertanam dan dapat menjawab setiap kebutuhan penggunananya. Sedangkan Dalam flexibility terdapat hybrid programming dan kebebasan. 


\section{METODE}

\section{Metode Pengumpulan Data}

Membagi pengumpulan data menjadi 2 kategori yaitu:

\section{Data Primer}

Studi Lapangan. Studi lapangan merupakan cara memperoleh data secara langsung dari lokasi dengan cara mengamati keadaan sekitar dan potensi yang dapat digunakan dalam perancangan. Observasi lingkungan dan membagikan questioner kepada orang-orang yang ada di kawasan Kelapa Gading dan memperhatikan tempat mana saja yang disebut sebagai Third place / tempat ketiga.

\section{Data Sekunder}

Studi Literatur. Studi literatur yang digunakan sebagai refrensi berupa, buku, jurnal arsitektur, artikel, hand out power point, dan karya ilmiah lainnya serta peraturan dan kebijakan pemerintah yang dapat dijadikan dasar untuk memperlancar analisis.

Studi Perbandingan Studi pembanding sebagai acuan untuk mengetahui apakah yang diartikan tempat ketiga oleh orang-orang di Kelapa Gading sama atau sesuai dengan yang diartikan oleh para ahli.

\section{Analisis Perancangan}

Dalam menganalisis, dilakukan beberapa pendekatan yang terdiri dari rangkaian pembahasan kondisi kawasan yang akan dirancang.

\section{Analisis Kawasan}

Analisis tapak bertujuan untuk mengetahui keadaan eksisting tapak dan program eksisting.

\section{Analisis Fungsi}

Menganalisis fungsi-fungsi yang sudah ada pada La Piazza.

\section{Analisis Aktivitas}

Mengamati secara langsung di La Piazza Kelapa Gading untuk mengetahui aktivitas yang ada pada kawasan tersebut sehingga dapat menjadi dasar untuk mendesign kebutuhan Third place / tempat ketiga

\section{DISKUSI DAN HASIL}

Berlokasi di dalam perumahan kelapa gading, la piazza baru (la piazza Third place), mempunyai tujuan untuk menciptakan tempat berkumpul komunitas dan masyarakat yang menenangkan dan dapat menjadi tempat istirahat sementara bagi orang - orang yang penat dengan suasana perkantoran. Dalam proyek ini beberapa struktur eksisting pada bangunan lama digunakan kembali, seperti basement, konektor menuju gedung parkir, konektor menuju mall kelapa gading, dan struktur dari eksisting gedung la La Piazza bagian utara. Dengan pertimbangan, pada bagian tersebut masih ada aktivitas yang masih aktif. 


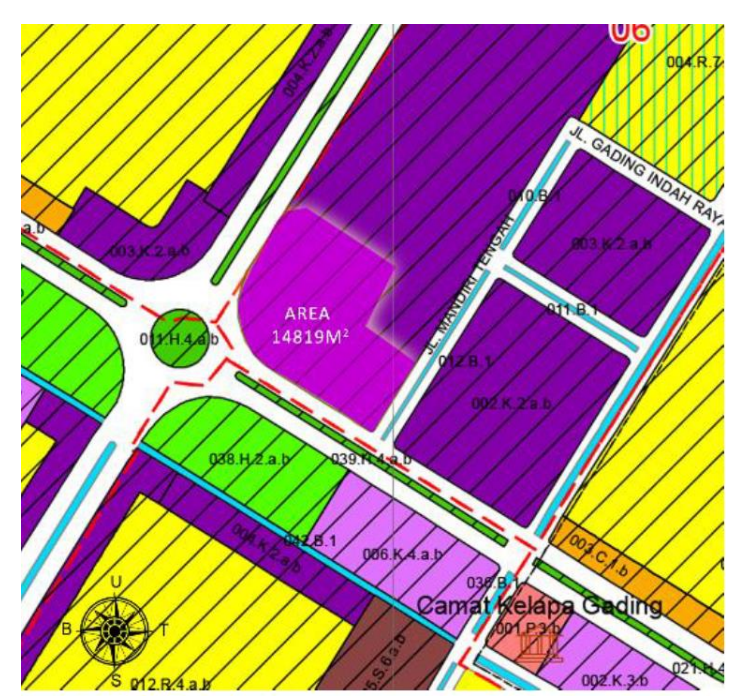

Gambar 1. Lokasi

Sumber: jakartasatu.jakarta.go.id 2019

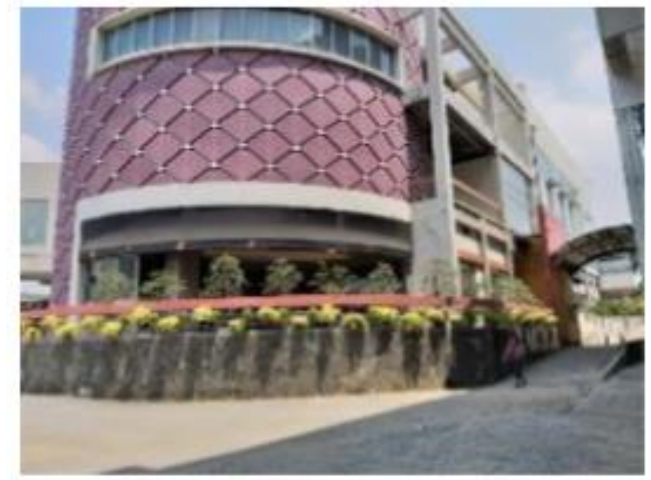

Gambar 2. Gedung La Piazza Bagian Utara

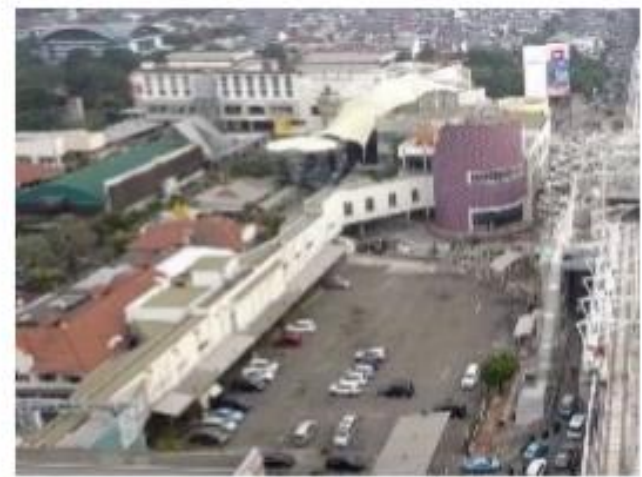

Gambar 3. Foto Udara Drone La Piazza Sumber: Penulis, 2019

La piazza Third place ini memiliki 5 akses masuk khusus seperti, akses la piazza - mall kelapa gading, la piazza - gading food city, la piazza - stasiun Irt, la piazza - menara satu bca, dan la piazza - gedung parkir. Sehingga kelima akses tersebut dijadikan sebagai bahan pertimbangan dalam mendesain pintu masuk proyek

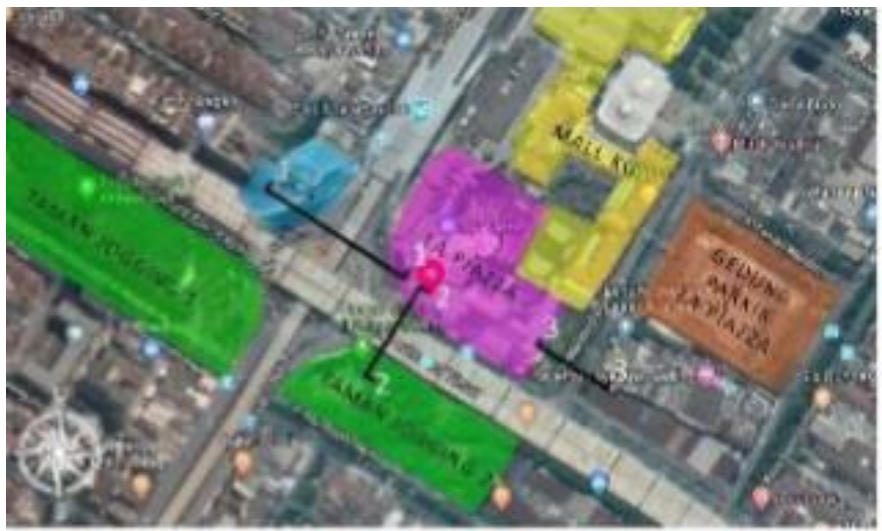

Gambar 4. Bangunan Sekitar Tapak Sumber: Penulis, 2019

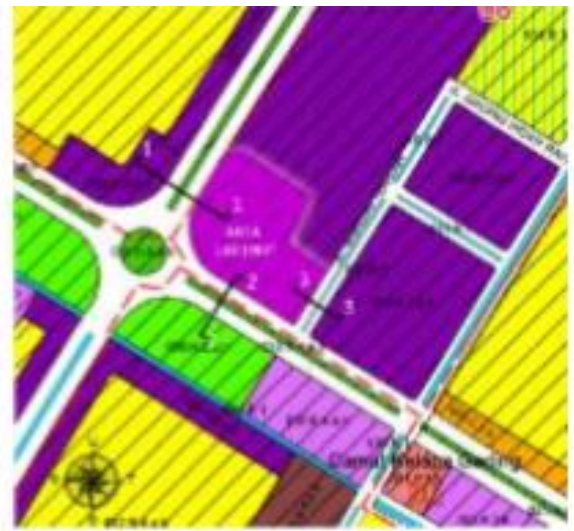

Gambar 5. Peraturan Zonasi

Sumber: jakartasatu.jakarta.go.id 2019 
Konfigurasi Tapak

KDB : $60 \%$

LUAS AREA X 60\% $14819 \times 60 \%=8891 \mathrm{M} 2$

KLB : 2.19

LUAS AREA X $2.1914819 \times 2.19=32453 \mathrm{M} 2$

$\mathrm{KDH}: 35 \%$

LUAS AREA X 35\% $14819 \times 35 \%=5186 \mathrm{M} 2$

KTB : $50 \%$

LUAS AREA X 50\% $14819 \times 50 \%=7409 \mathrm{M} 2$

GSB : $5 \mathrm{M}$

KB : 5 LT

Terdapat 2 halte yang difasilitasi dengan angkutan umum yang melewati tapak. Yaitu halte Artha Gading dan halte Pulomas. Jalur angkutan umum digambarkan dengan garis warna hijau dan kuning. Angkutan umum bertemu di jalan Boulevard Raya, sehingga diperlukan tempat untuk menurunkan penumpang angkutan umum tersebut. Tapak juga dilewati dengan jalur pesepeda, yang digambarkan dengan garis merah maroon. Jalur tersebut melewati jalan Boulevard Timur, sehingga perlu adanya akses dari jalan tersebut untuk pesepeda yang ingin mendatangi tapak.

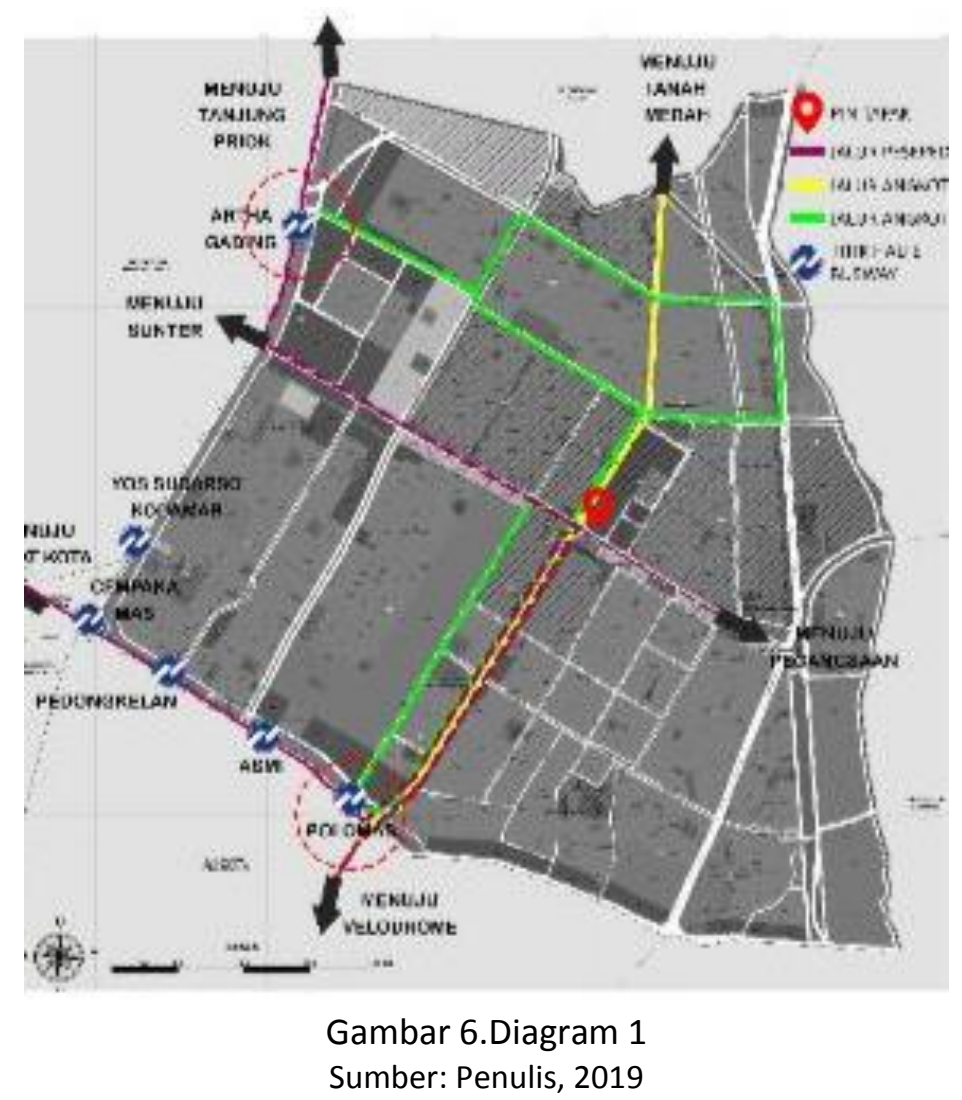

Survei dan Quesioner 


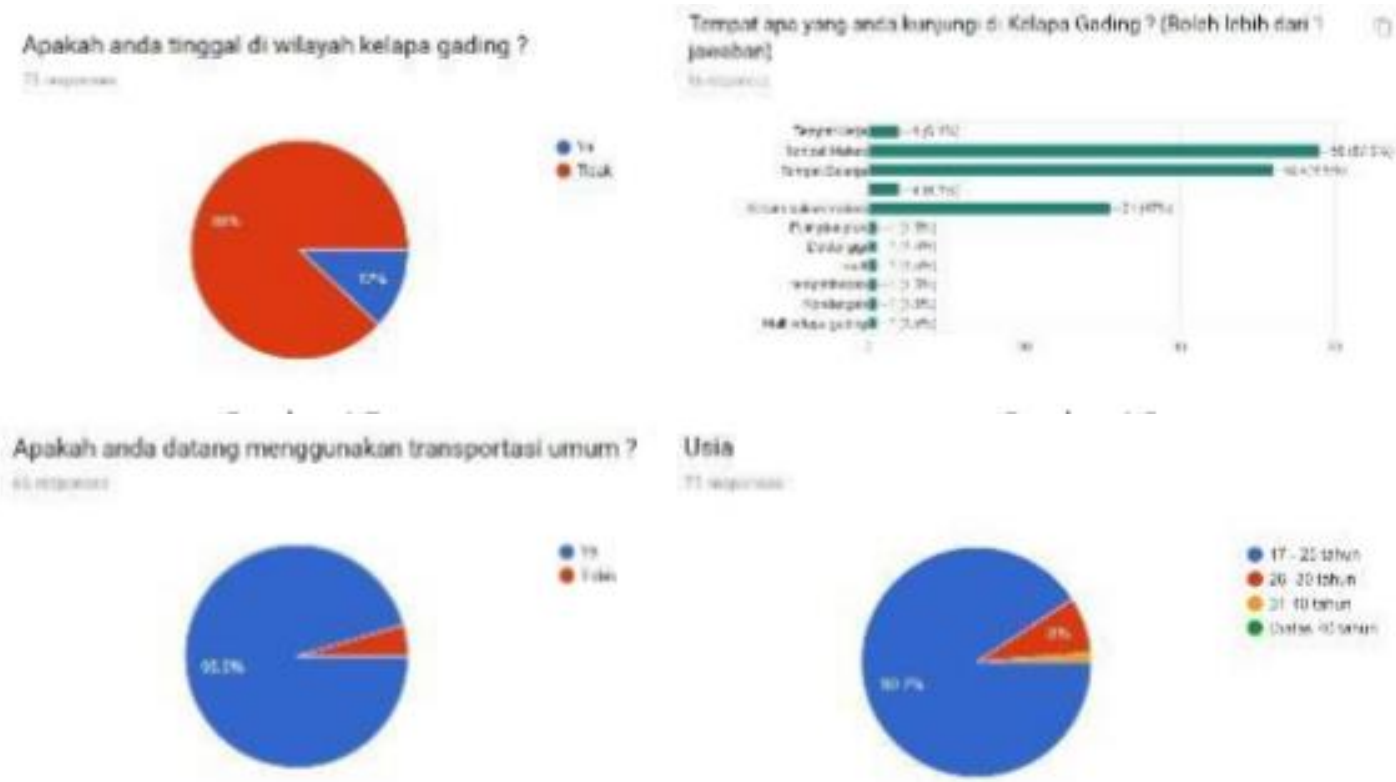

Gambar 7.Hasil Quesioner

Sumber: Penulis, 2019

Menurut diagram diatas dapat disimpulkan bahwa mayoritas orang yang mengisi quesstioner tersebut, datang ke Kelapa Gading untuk mencari makan dan berbelanja. 95\% dari 66 responden quesioner datang menggunakan transportasi umum. $90 \%$ responden quesioner memiliki batas umur antara 17-25 tahun, sehingga berdasarkan survei yang sudah dilakukan dapat dikatakan pengunjung yang datang ke Kelapa Gading, sebagian besar merupakan anak milenial.

\section{Analisis Tapak}

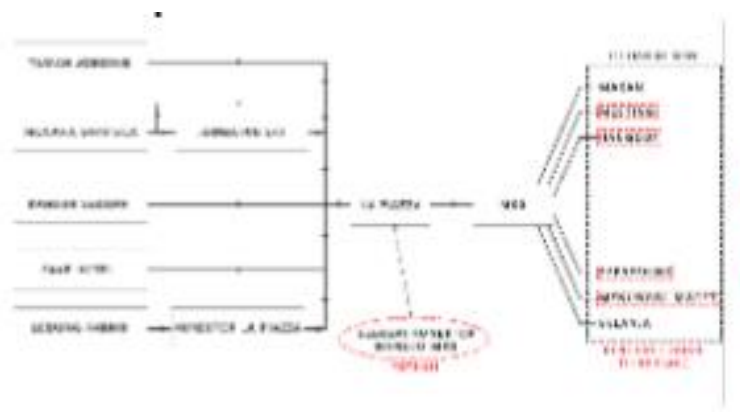

Gambar 8. Diagram Pergerakan Orang Sekitar Tapak Sumber: Penulis, 2019

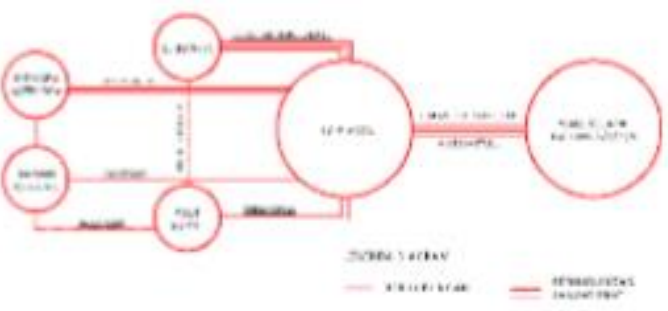

Gambar 9. Diagram Hubungan Tapak dengan Lingkungan Sekitar Sumber: Penulis, 2019

Dari diagram diatas dapat disimpulkan bahwa La Piazza sebagai konektor menuju Mall Kelapa Gading. Sehingga La Piazza mempunyai potensi sangat besar untuk pengunjung melewati tempat tersebut. Menurut hasil survei, pengunjung yang datang ke Mall Kelapa Gading khususnya pada siang hari, memiliki tujuan untuk bertemu klien, berkumpul dengan komunitas, dan istirahat sejenak untuk melepas stress. Sedangkan pada sore hari, pengunjung Mall Kelapa Gading, selain mencari makan, juga menunggu macet reda. Tujuan-tujuan tersebut nantinya akan menjadi pertimbangan sebagai program yang ada didalam La Piazza. 
Penggabungan program lama dan baru sebagai berikut :

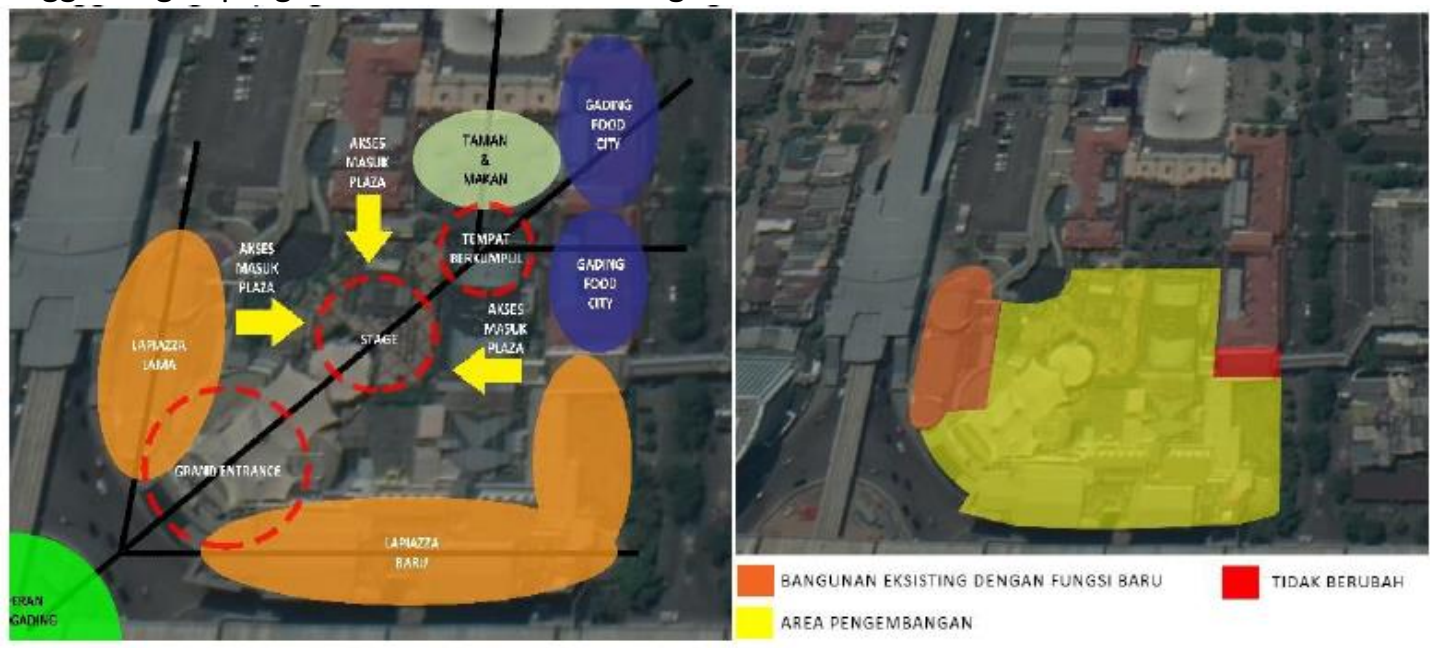

Gambar 10. Zoning Baru Tapak

Sumber: Penulis, 2019
Gambar 11. Area Desain

Sumber: Penulis, 2019

Bangunan La Piazza yang dipakai, hanya struktur bagian utara yang ditandai dengan warna jingga, fungsi dan zoning ruangan mengikuti desain baru, dan sisanya merupakan area desain baru. Posisi panggung dipindah lokasinya menjadi ditengah. Desain ini termasuk adanya area grand entrance untuk memfasilitasi pesepeda dari dan ke Kelapa Gading, serta pedestrian yang menggunakan transportasi umum. Sirkulasi sekitar tapak sebagai berikut:

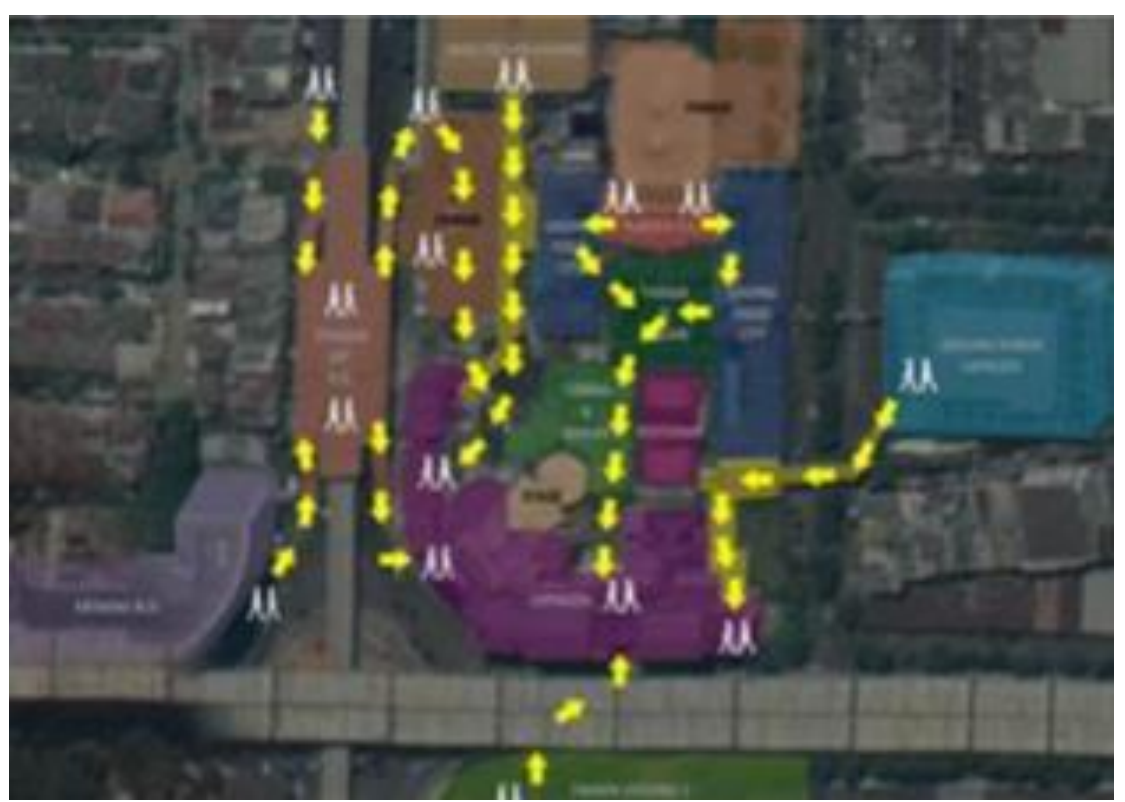

Gambar 12. Sirkulasi Pedestrian di Sekitar Tapak

Sumber: Penulis, 2019

Titik awal arah pedestrian dibagi menjadi 7 titik, yaitu dari Menara Satu BCA, Stasiun LRT, Taman Jogging 2, Gedung Parkir La Piazza, Hotel seberang La Piazza, Gading Food City, dan Mall Kelap Gading. Untuk itu sirkulasi dalam La Piazza didesain sebagai berikut, 


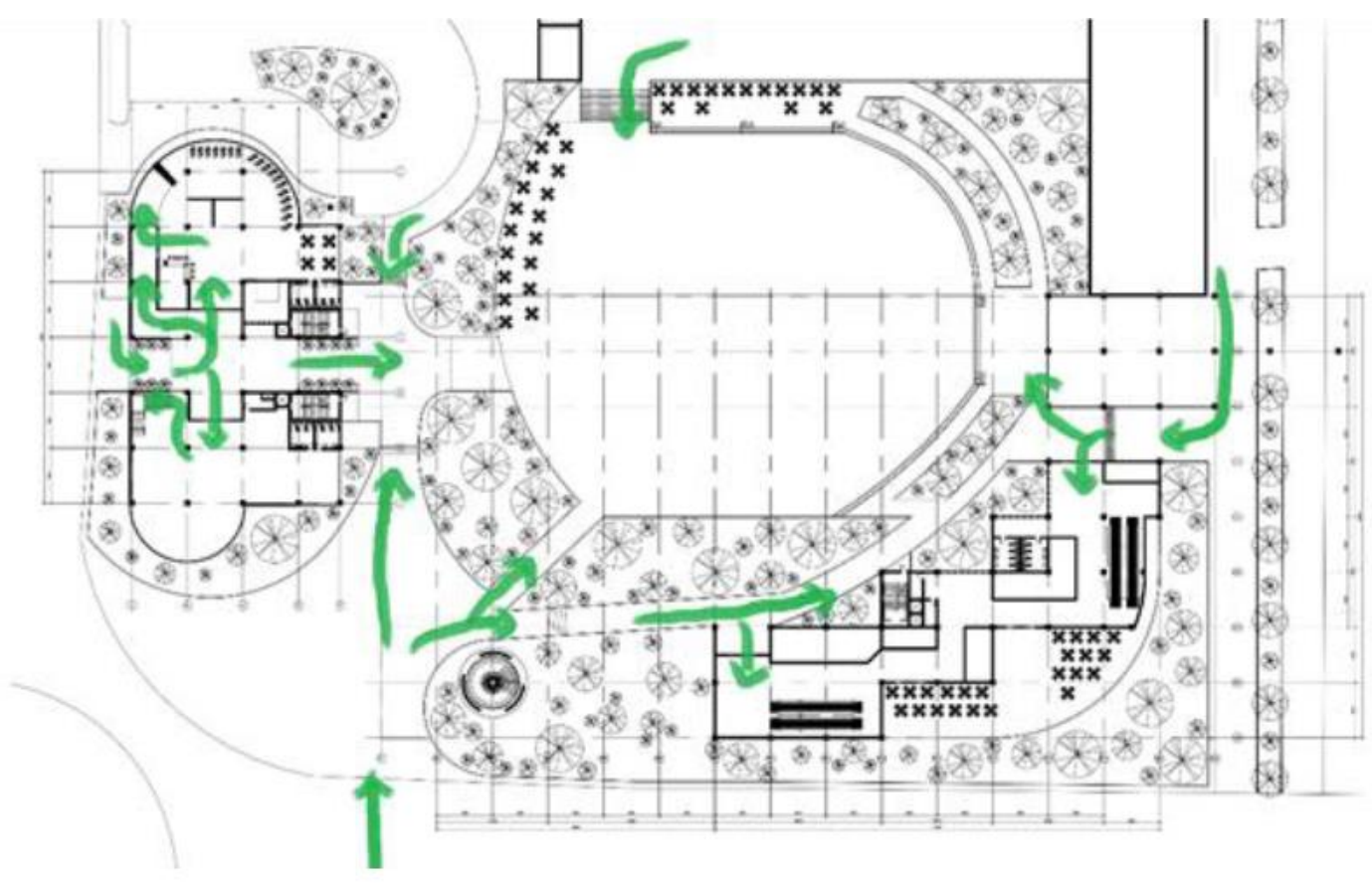

Gambar 13. Sirkulasi Pejalan Kaki

Sumber: Penulis, 2019

Sedangkan sirkulasi kendaraan dalam tapak mengikuti eksisting, dengan satu drop-off di La Piazza bagian utara, dan parkiran kendaraan pada basement, digambarkan sebagai berikut,

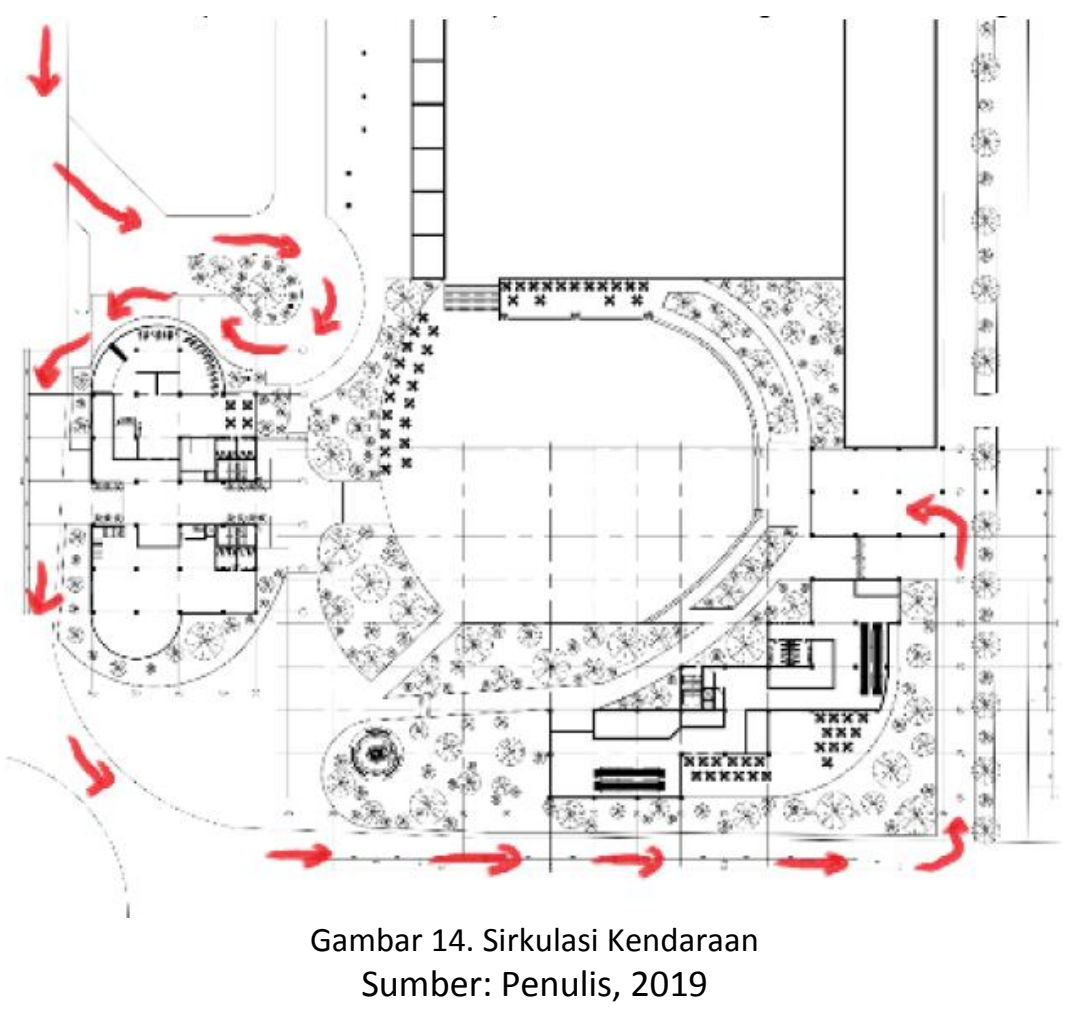

La Piazza Third place memiliki desain yang baru mengutamakan konsep open architecture dan architecture for the Third place juga konsep hutan. sehingga desain pada bangunan baru selain 
memiliki ruang - ruang yang terbuka untuk umum dan ruang komunitas, juga memberikan kesan terbuka dan mengundang serta sejuk dan tenang. Terdapat 3 elemen hutan yang diterapkan pada bangunan, yaitu air, tanaman hijau dan cahaya matahari. 3 hal tersebut dapat merelaksasi orang yang sedang banyak pikiran dan stress akan pekerjaan khususnya orang - orang yang bekerja di kantoran, menurut penelitian regent's university london.

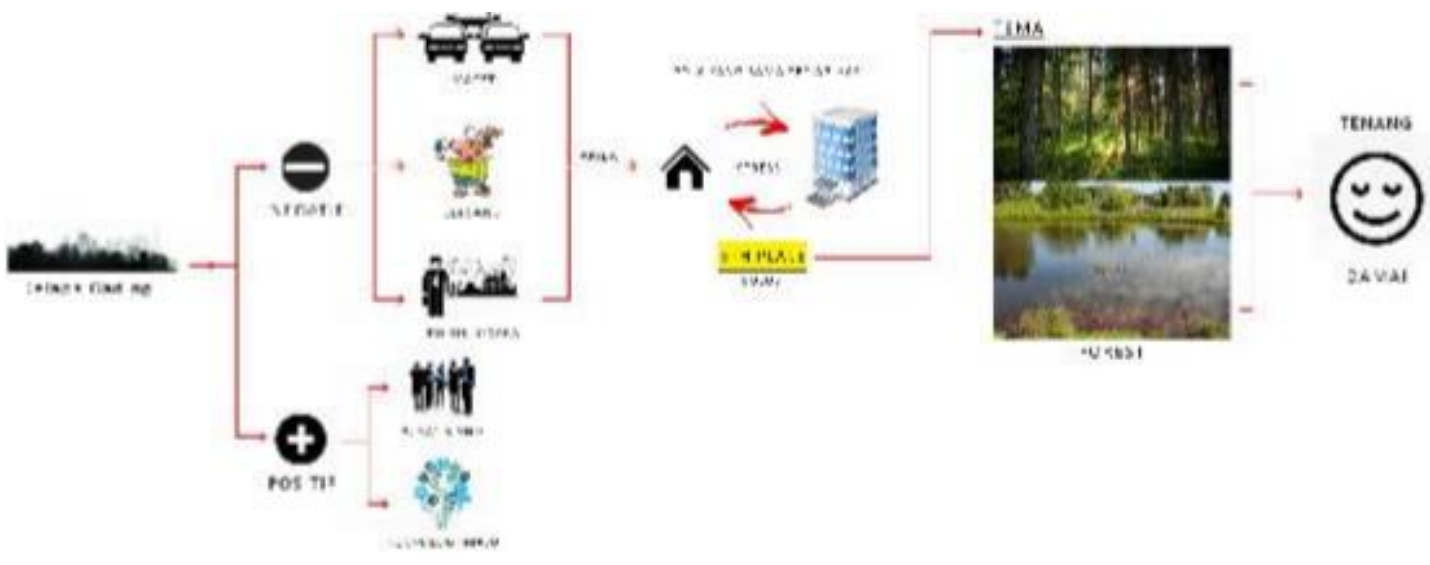

Gambar 15. Diagram Konsep

Sumber: Penulis, 2019

Proses pembentukan gubahan massa sebagai berikut,

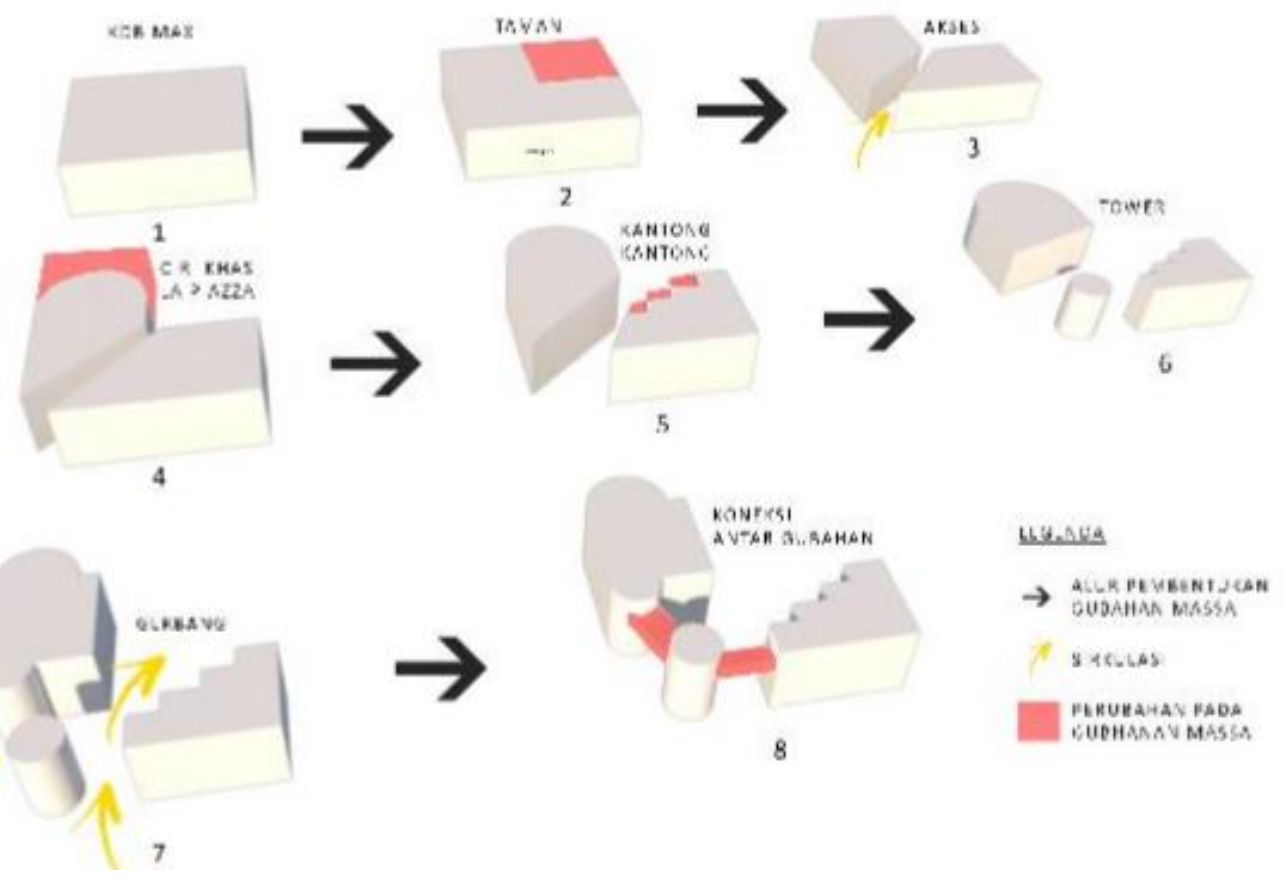

Gambar 16. Gubahan Massa

Sumber: Penulis, 2019 
Program ruang yang ada pada tapak adalah sebagai berikut :

Tabel 1. Tabel Program Ruang La Piazza

\begin{tabular}{|c|c|c|c|}
\hline No & Nama & Jumlah & Area $\left(\mathrm{M}^{2}\right)$ \\
\hline \multicolumn{4}{|c|}{ Co Working Space } \\
\hline 1 & Co Working Space 1 & 1 & 1248 \\
\hline 2 & Co Working Space Outdoor & 1 & 1000 \\
\hline 3 & Toilet & 1 & 46 \\
\hline \multicolumn{3}{|c|}{ Total } & 2294 \\
\hline \multicolumn{4}{|c|}{ Bike Community } \\
\hline 2 & Workshop & 1 & 67 \\
\hline 3 & Store Tenant & 1 & 200 \\
\hline 4 & Mini Café & 1 & 228 \\
\hline 5 & Bike Community Area & 1 & 400 \\
\hline 7 & Toilet & 2 & 55 \\
\hline \multicolumn{3}{|c|}{ Total } & 950 \\
\hline \multicolumn{4}{|c|}{ Komunitas Fitness } \\
\hline 1 & R. Fitness & 1 & 1941 \\
\hline 3 & Toilet & 2 & 119 \\
\hline \multicolumn{3}{|c|}{ Total } & 2060 \\
\hline \multicolumn{4}{|c|}{ Café \& Restoran } \\
\hline 1 & Café & 1 & 1081 \\
\hline 4 & Restoran & 1 & 1472 \\
\hline 5 & Dapur & 1 & 208 \\
\hline 6 & Toilet & 1 & 73 \\
\hline \multicolumn{3}{|c|}{ Total } & 2834 \\
\hline \multicolumn{4}{|c|}{ Pengelola } \\
\hline 1 & Pengelola & 1 & 655 \\
\hline \multicolumn{3}{|c|}{ Total } & 655 \\
\hline \multicolumn{4}{|c|}{ Taman } \\
\hline \multicolumn{4}{|c|}{ Service } \\
\hline 1 & R. LVMPD & 1 & 2 \\
\hline 2 & R. Genset & 1 & 15 \\
\hline 3 & R. Travo & 1 & 18 \\
\hline 4 & R. Panel & 1 & 20 \\
\hline 5 & R. AHU & 1 & 20 \\
\hline 6 & R. Pompa & 1 & 15 \\
\hline 7 & R. PABX & 1 & 9 \\
\hline \multicolumn{3}{|c|}{ Total } & 99 \\
\hline \multicolumn{3}{|c|}{ Total Keseluruhan } & 8892 \\
\hline
\end{tabular}

Sumber: Sumber: Penulis, 2019

Perspektif Output desain akhir sebagai berikut :

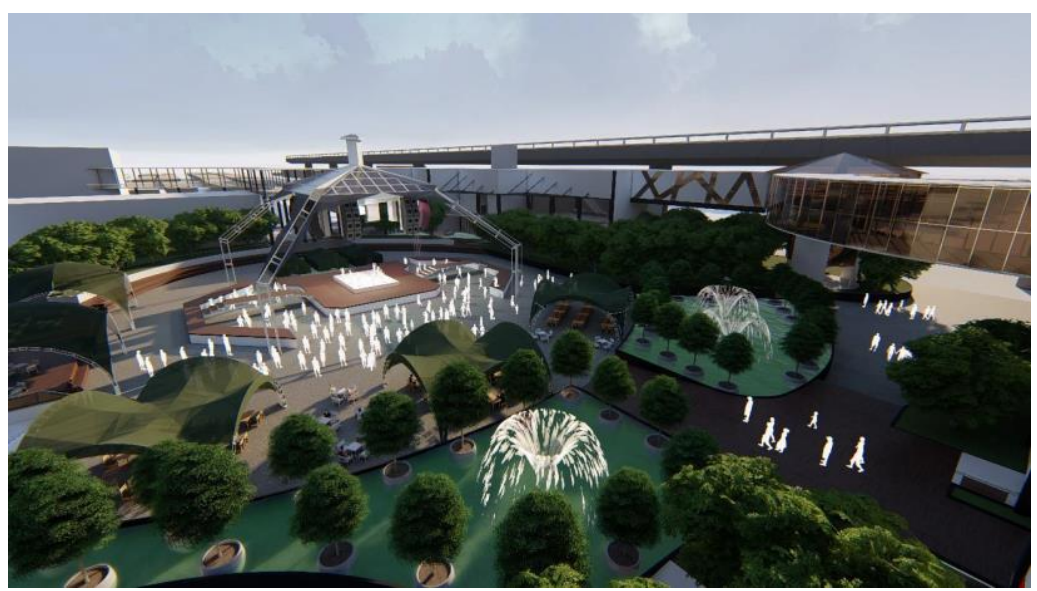

Gambar 17. La Piazza Third place

Sumber: Penulis, 2019 


\section{KESIMPULAN DAN SARAN}

Tempat ketiga merupakan tempat dimana orang bertemu yang aktivitas utamanya adalah percakapan. Tempat netral yang didalamnya ada kesetaraan suku, ras, umur, etnis, tingkatan sosial, dll. Tempat ini juga harus mudah diakses, dan mempunyai pelanggan tetap. Tempat ketiga perlu merepresentasikan pengalaman pribadi seseorang serta memenuhi kebutuhan pribadinya. La Piazza merupakan salah satunya, namun belum berfungsi dengan baik. Dengan adanya program-program dan desain baru pada La Piazza diharapkan dapat mengembalikan fungsi sebagai tempat ketiga di Kelepa Gading. Dengan mengaktifkan kembali fungsi La Piazza sebagai tempat ketiga di Kelapa Gading karena memiliki potensi yang sangat besar dikarnakan lokasinya yang strategis, merupakan titik temu antar angkutan umum, memiliki akses ke stasiun LRT dan sebagai konektor yang menghubungkan Hotel sekitar, Taman Jogging, Menara Satu BCA ke Mall Kelapa Gading.

\section{REFERENSI}

Anne P., C. (2011) Rethinking Oldenburg: Third places and Generation Y in a Developing Country Context

Florida, R. (2012). The Rise of the Creative Class, Revisited-Basic Books.

Fraser, N. (1992) Rethinking the public sphere: a contribution to the critique of actually existing democracy, in Calhoun, C. (ed.) Habermas and the Public Sphere. Cambridge, MA and London: The MIT Press, pp. 109-142.

Mills, G. H. S. From A Third place To Thirdspace [And Beyond] : A Genesis And Dissection Of The 'Laptop In The Coffee Shop' As An Urban Public Phenomenon

Oldenburg, R. (1989). The Great Good Place: Cafes, Coffee Shops, Community Centers, Beauty Parlors, General Stores, Bars, Hangouts, and How They Get You Through the Day. New York: Paragon House.

Soja, E. W. (1996). Thirdspace: journeys to Los Angeles and other realandimagined places . Cambridge, Mass: Blackwell. Diunduh 11 November 2019 <http://s3.amazonaws.com/arenaattachments/1634955/44c50d0d25fb8a02f8813756c09 9dbd3.pdf?1516718155> 